\title{
ROLE OF LYCOPENE IN THE MANAGEMENT OF ORAL SUBMUCOUS FIBROSIS.
}

\begin{abstract}
:
Objective: In this study we investigate the effectiveness of lycopene in the management of oral submucous fibrosis (OSF) when intralesional steroids also given in combination. Methodology: This cross sectional study was done in Dental Section Allied Hospital, Faisalabad, Fatima Jinnah Hospital, Multan and Nishtar Institute of Dentistry, Multan in duration of six months from September 2017 to April 2018. This cross sectional study was initiated after approval from hospital ethical board. Collected Information was entered in SPSS computer software version 23.1 and analyzed for possible results. Mean and SD was calculated and presented for quantitative data like age, VAS score and mouth opening. Frequency (percentages) were calculated and presented for qualitative data such as gender. Post stratification statistical chi square test was used to see effect modification. P value $\leq 0.05$ was considered as significant. Results: Overall, there were $100 \%(n=354)$ patients. Total patients who were selected for the study had the habit of chewing areca nut either in natural form or in the form of Pan Masala, gutkha or mawa. Gutkha is the most common form of areca nut used, i.e. $65.8 \%(n=233)$ patients were using it. In pour study average increase in mouth opening from baseline (before treatment) was $2.34 \pm 1.03 \mathrm{~mm}$ in group A. $4.20 \pm 1.26 \mathrm{~mm}$ in group B and 3.40 $\pm 0.19 \mathrm{~mm}$ in group $\mathrm{C}$ at six week. Conclusion: When Lycopene used combined with intralesional steroids and Hyaluronidase its effectiveness is better in improving the mouth opening its symptoms in patients with Oral Submucous Fibrosis (OSF). It was also found that there was no side effects.
\end{abstract}

Muhammad Yasir Aslam ${ }^{1}$, Attika Batool ${ }^{2}$, Fozia Khanam ${ }^{3}$

1. House Officer Nishtar Institute of Dentistry Mulatn

2. House Offer Dental Section Allied Hospital, Faisalabad

3. Senior Medical Officer Fatima Jinnah Hospital, Multan

Correspounding Author: dr.attika@gmail.com

Keywords: Lycopene, OSF, Mouth opening, burning sensation.

DOI: $10.7176 / \mathrm{JMPB} / 52-15$

\section{Introduction}

Oral sebaceous fibrosis (OSF) is a malignant disease of oral cavity sometime chronic in nature and may affect pharynx (1). From last few years it is a conflict of interest and under debate issue due to its chronic resistant nature. In Asia OSF was predominantly found in Indian population (2). In many studies various factors were reported such as ; hypersensitivity, deficiency of vitamin B12, capsaicin, autoimmunity, chronic iron deficiency and betel nut alkaloids, most common of which is chewing areca (3). Chewing areca increase the formation of collagen that stimulates production of free radicals in body which may lead to fibrosis. Increase production of free radicals also responsible for high oxidation of fatty acids and affects contents of cell membrane which may results tumor formation (4). Areca chewing is a common mouth freshener used in Indian community and have deep roots in their history. Excessive use of areca chewing an(5)d its contents ulcerate the cell structures like, nucleic acid, lipids, proteins and cell membrane (6). Its use also denatured the vitamins, creates malnutrition and damages the mucosa of oral cavity $(7,8)$. When dentists concern about its treatment modalities antioxidants are the best choices which stabilize free radicals in early phase of cell involvement. A most effective antioxidant is lycopene, synthesized by the plants and microorganisms. Lycopene is stronger antioxidant than alpha tocopherol (lycopene is ten times stronger) and beta carotenes (lycopene is twice more stronger) $(9,10)$. Among available antioxidants no one have ability.

\section{Methodology:}

This cross sectional study was done Dental Section Allied Hospital, Faisalabad, Fatima Jinnah Hospital, Multan and Nishtar Institute of Dentistry, Multan in duration of six months from September 2017 to April 2018. This cross sectional study was initiated after approval from hospital ethical board; informed written consent was obtained from patients or their attendants and ensured about confidentiality/privacy. Sample size of study was calculated with WHO approved sample size calculator by using following characteristics: Confidence Interval 95\%, Power of study $80 \%$ proportion of accuracy use (p) $64.4 \%$ by using non probability consecutive sampling technique. Patients with history of chewing arecanut and its products, burning on ingestion of fast food, limited mouth opening 
without use of band (palpable and non palpable) were included in the study. Patients of malignant OSF diagnosed histologically were excluded from the study.

After complete prophylaxis and detailed information about severity and malignancy condition patients were counseled to stop chewing arecanut. Total number of patients were grouped as group A, B and C. patients in group A were treated with Lycopene capsule $(16 \mathrm{mg})$, single capsule daily and dexamethasone $1.5 \mathrm{mg}$ and "Hyaluronidase 1500 IU mixed with lignocaine injection" two times in a week. Group B were given oral multivitamins daily plus intralesional dexamethasone injection $1.5 \mathrm{mg}$ two times in a week and Hyaluronidase 1500 IU mixed with lignocaine. In group $\mathrm{C}$ patients were given only weekly intralesional injections of Dexamethasone $1.5 \mathrm{ml} \&$ Hyaluronidase $1500 \mathrm{IU}$ with lignocaine two times in a week without any other supplement. All patients were followed up upto six weeks and evaluated at every week for; Habits, mouth opening and burning sensation. All parameters were recorded before start of treatment and considered as baseline and then on every week for comparison of betterment. Burning sensation was measured by measuring VAS score. Size of mouth opening was recorded by measurement of interincisal distance from the mesioincisal edge of the maxillary right central incisor to the mesioincisal edge of the mandibular right central incisor by using a measuring instrument (vernier calipers). If any tooth was missing other side was used for measurement of distance or mouth opening.

Collected Information was entered in SPSS computer software version 23.1 and analyzed for possible results. Mean and SD was calculated and presented for quantitative data like age, VAS score and mouth opening. Frequency (percentages) were calculated and presented for qualitative data such as gender. Post stratification statistical chi square test was used to see effect modification. P value $\leq 0.05$ was considered as significant.

\section{Results:}

Overall, there were $100 \%(n=354)$ patients. Patients with habit of chewing areca nut and its products like; mawa, Pan Masala and gutka were included in the study. About 65.8\% patients have habit of chewing gutka. Duration of habits was $5.06 \pm 2.01$ years. (Range: 1 to 12 years).

The study population was subdivided into three groups; $33.33 \%(n=118)$ in each of the three groups. The mean age and VAS score of the patients, in group A, was $32.27 \pm 6.15$ years and $6.85 \pm 1.77$ respectively. There were $99.2 \%(n=117)$ males and $0.8 \%(n=1)$ female, in group A. In group B age and VAS score was $30.92 \pm 6.68$ years and $7.03 \pm 1.86$ respectively. There were $93.2 \%(n=110)$ males and $6.8 \%(n=8)$ females in group B. In group $\mathrm{C}$ age and VAS score was $32.66 \pm 6.42$ years and $7.28 \pm 1.62$ respectively. There were $98.3 \%(\mathrm{n}=116)$ males and $1.7 \%$ $(\mathrm{n}=2)$ females, in group C. (Table-1).

\section{Group A}

Mouth opening from baseline measurement (before treatment) was $2.34 \pm 1.03 \mathrm{~mm}$ at week six. After complete treatment the mean distance of mouth opening from 1 week to sixth week was $1.8 \pm 0.95 \mathrm{~mm}, 2.79 \pm 1.16$ $\mathrm{mm}, 3.22 \pm 1.51 \mathrm{~mm}, 4.2 \pm 1.23 \mathrm{~mm}, 4.44 \pm 1.0 \mathrm{~mm}$ and $5.08 \pm 1.05 \mathrm{~mm}$ respectively in group number A. When mean mouth opening values of six weeks (1-6 weeks) were compared with the baseline values, it was found that p-values $0.000,0.000,0.000,0.000,0.000$ respectively, these values are statistically significant, except week 2 i.e. $p=0.438$. (Table-2)

\section{Group B}

When mouth opening was compared with before treatment values to week 6 was $4.20 \pm 1.26 \mathrm{~mm}$. when post treatment values were compared mouth opening, from 1 to 6 weeks, was $1.15 \pm 0.83 \mathrm{~mm}, 2.44 \pm 1.14 \mathrm{~mm}$, $3.47 \pm 0.55 \mathrm{~mm}, 3.84 \pm 0.73 \mathrm{~mm}, 4.47 \pm 0.84 \mathrm{~mm}$ and $4.5 \pm 0.61 \mathrm{~mm}$ respectively, in group B. On comparison of mouth opening from 1-6 weeks with before treatment values, p-values $0.000,0.000,0.000,0.025,0.020$ respectively statistically significant, except week 5 i.e. $p=0.853$. (Table-3)

\section{Group C}

When mouth opening was compared with before treatment values to week 6 was $3.40 \pm 0.19 \mathrm{~mm}$. After treatment the mean mouth opening, from 1 to 6 weeks, was $1.57 \pm 1.48 \mathrm{~mm}, 1.98 \pm 0.53 \mathrm{~mm}, 2.6 \pm 0.56 \mathrm{~mm}$, $3.23 \pm 0.80 \mathrm{~mm}, 3.5 \pm 0.96 \mathrm{~mm}$ and $4.6 \pm 0.94 \mathrm{~mm}$ respectively, in group C. On comparison of average mouth opening from week 1-6 with before treatment values, it was found p-values $0.000,0.000,0.036,0.013,0.000$ and 0.000 respectively statistically significant. (Table-4) 
On comparison of average mouth opening among all the three groups (A, B and C), there was significant difference between the groups $(\mathrm{p}=0.000)$. (Table-5)

Table. 1

Demographic Variables

\begin{tabular}{|c|c|c|c|c|}
\hline Variable & Group A & Group B & Group C & Test of Sig. \\
\hline Gender & $\mathrm{M}=99.2 \%, \mathrm{~F}=0.8 \%$ & $\mathrm{M}=93.2 \%, \mathrm{~F}=6.8 \%$ & $\begin{array}{c}\mathrm{M}=98.3 \%, \\
\mathrm{~F}=1.7 \%\end{array}$ & $\begin{array}{c}\chi^{2}=8.096 \\
p=0.018\end{array}$ \\
\hline Age & $32.27 \pm 6.15$ years & $30.92 \pm 6.68$ years & $32.66 \pm 6.42$ years & $\begin{array}{l}\mathrm{t}=1.611 \\
\mathrm{p}=0.108\end{array}$ \\
\hline VAS Score & $6.85 \pm 1.77$ & $7.03 \pm 1.86$ & $7.28 \pm 1.62$ & $\begin{array}{l}\mathrm{t}=-0.749 \\
\mathrm{p}=0.454\end{array}$ \\
\hline
\end{tabular}

Table-2: Mouth opening changes during treatment in A group

\begin{tabular}{|l|c|c|}
\hline Duration & $\begin{array}{c}\text { Change Mouth } \\
\text { Opening (mm) }\end{array}$ & Test of Sig. \\
\hline Week 1 & $1.8 \pm 0.95$ & $\mathrm{t}=3.764$ \\
\hline Week 2 & $2.79 \pm 1.16$ & $\mathrm{p}=0.000$ \\
\hline Week 3 & $3.22 \pm 1.51$ & $\mathrm{t}=-0.781$ \\
\hline Week 4 & & $\mathrm{t}=-4.254$ \\
& & $\mathrm{p}=0.000$ \\
\hline Week 5 & $4.2 \pm 1.23$ & $\mathrm{t}=-7.206$ \\
& & $\mathrm{p}=0.000$ \\
\hline & & $\mathrm{t}=-8.089$ \\
\hline
\end{tabular}


Table-3: Mouth opening changes during treatment in B group

\begin{tabular}{|l|c|c|}
\hline Duration & $\begin{array}{c}\text { Change Mouth } \\
\text { Opening (mm) }\end{array}$ & Test of Sig. \\
\hline Week 1 & $1.15 \pm 0.83$ & $\mathrm{t}=13.584$ \\
& & $\mathrm{p}=0.000$ \\
\hline Week 2 & $2.44 \pm 1.14$ & $\mathrm{t}=8.509$ \\
& & $\mathrm{p}=0.000$ \\
\hline Week 3 & $3.47 \pm 0.55$ & $\mathrm{t}=5.496$ \\
\hline Week 4 & & $\mathrm{p}=0.000$ \\
\hline & $3.84 \pm 0.73$ & $\mathrm{t}=2.306$ \\
Week 5 & & $\mathrm{p}=0.025$ \\
\hline & $4.47 \pm 0.84$ & $\mathrm{t}=-0.186$ \\
Week 6 & & $\mathrm{p}=0.853$ \\
\hline
\end{tabular}

Table-4: Mouth opening changes during treatment in A group

\begin{tabular}{|l|c|c|}
\hline Duration & $\begin{array}{c}\text { Change Mouth } \\
\text { Opening (mm) }\end{array}$ & Test of Sig. \\
\hline Week 1 & $1.57 \pm 1.48$ & $\mathrm{t}=12.835$ \\
Week 2 & $1.98 \pm 0.53$ & $\mathrm{p}=0.000$ \\
\hline & & $\mathrm{t}=7.525$ \\
Week 3 & $2.6 \pm 0.56$ & $\mathrm{p}=0.000$ \\
\hline & & $\mathrm{t}=2.146$ \\
Week 4 & $3.23 \pm 0.80$ & $\mathrm{p}=0.036$ \\
\hline & & $\mathrm{p}=-2.588$ \\
Week 5 & $3.5 \pm 0.96$ & $\mathrm{t}=-4.185$ \\
\hline Week 6 & & $\mathrm{p}=0.000$ \\
\hline
\end{tabular}


Table-5: Comparison of mouth opening between groups at six weeks and baseline

\begin{tabular}{|c|l|c|c|c|}
\hline $\begin{array}{c}\text { Time Points } \\
\text { Compared }\end{array}$ & \multicolumn{1}{|c|}{ Group } & Mean \pm S.D & F-Value & P-value \\
\hline \multirow{2}{*}{$\begin{array}{c}\text { Week o to } \\
\text { Week 6 }\end{array}$} & A & $2.34 \pm 1.03$ & 341.11 & 0.000 \\
\cline { 2 - 3 } & B & $4.20 \pm 1.26$ & & \\
\cline { 2 - 3 } & C & $3.40 \pm 0.19$ & & \\
\hline
\end{tabular}

\section{Discussion:}

Lycopene is main carotenoid mostly found in tomatoes, having potent anticancer activity in variety of cancer (11). Antioxidant activity of lycopene have role in treatment of many chronic diseases and in early symptoms. In many oral diseases like OSF, leukoplakia and malignant lesions lycopene play an important role for the management plan (12).

Nidhi Elizabeth et al (13) conducted a study on comparison of lycopene and multivitamins and concluded that when Lycopene was administered combined with intralesional steroids and Hyaluronidase drugs it was found that lycopene is too much effective in treatment of mouth opening and its symptoms when used in patients with Oral Submucous Fibrosis OSF.

Kaur $\mathrm{H}$ et al (14) also conducted a study on this topic and concluded that Lycopene and intralesional steroids and Hyaluronidase is significantly effective in treatment of OSF by improving the mouth opening and reducing the symptoms of OSF there were no side effects were reported with its use.

Selvam NP et al (15) conducted a study on lycopene and its effectiveness in OSF and concluded that Lycopene in combination with intralesional steroids and Hyaluronidase is more effective than any other drug in combination or alone which are used in treatment of OSF.

Dipti Singh et al (16) conducted a study on use of lycopene and intralesional injection of steroids and concluded that Lycopene is better than intralesional betamethasone injectable in improvement of mouth opening and reduction of burning sensation.

Katharia et al (17) reported in his study that in the treatment plan of OSMF, with intralesional placental extracts the burning sensation improved by $40.2 \%$ and Anshumalee $\mathrm{N}$ et al (18) reported $54-60 \%$ reduction in burning sensation with IFN on comparison of both groups it was observed mean burning sensation in Group I was high and significant as compared to Group II. P was $<0.001$.

Lycopene have an important role in inhibition of hepatic fibrosis in rats and in human fibroblast activity in vitro conditions. So, it can be used in the management of OSMF Kitade et al (19).

Kopuri RK et al (20) conducted a study on efficacy of lycopene and concluded that Lycopene have better results when compared to curcumin in the management of OSMF, but when studies conducted on larger sample size and prolong follow-ups are necessary for better understanding the role of curcumin in the management of OSMF and its symptoms.

\section{Conclusion}

When Lycopene used combined with intralesional steroids and Hyaluronidase its effectiveness is better in improving the mouth opening its symptoms in patients with Oral Submucous Fibrosis (OSF). It was also found that there was no side effects.

\section{References:}

1. Shamila H, Andrabi SAH, Imtiyaz A. Socio-demographic factors associated with sputum positivity rates for Tuberculosis in patients with cough in Srinagar hospital, India. Pacific J Med Sci. 2012;9(2):47-52.

2. Chole RH, Gondivkar SM, Gadbail AR, Balsaraf S, Chaudhary S, Dhore SV, et al. Review of drug treatment of oral submucous fibrosis. Oral oncol. 2012;48(5):393-8. 
3. Gupta M, Mishra P, Shrivastava K, Singh N, Singh P. Oral Submucous Fibrosis-Current Concepts of Aetiology \& its Management. J Applied Dent Med Sci. 2015;1(1):28-39.

4. Mohammad H, Hadi NI, Younus S, Ahmed F, Younus N. POTENTIALLY SIGNIFICANT BIOMARKERS IN ORAL SUBMUCOUS FIBROSIS. Pak J Med Dent. 2015;4(02):51-6.

5. Ganie SA, Dar TA, Bhat AH, Dar KB, Anees S, Zargar MA, et al. Melatonin: a potential anti-oxidant therapeutic agent for mitochondrial dysfunctions and related disorders. Rejuvenation Res. 2016;19(1):21-40.

6. Asif M, Khodadadi E. Medicinal uses and chemistry of flavonoid contents of some common edible tropical plants. J Paramed Sci. 2013;4(3):119-38.

7. Mouritsen OG. Gastrophysics of the oral cavity. Curr Pharm Des. 2016;22(15):2195-203.

8. Caffrey PB, Frenkel GD, Mcandrew KL, Marks K. A Model of the Development of Cisplatin Resistance in Human Small Cell Lung Cancer Xenografts. In Vivo. 2016;30(6):745-9.

9. Aslani BA, Ghobadi S. Studies on oxidants and antioxidants with a brief glance at their relevance to the immune system. Life sci. 2016;146:163-73.

10. Burton-Freeman B, Sesso HD. Whole food versus supplement: comparing the clinical evidence of tomato intake and lycopene supplementation on cardiovascular risk factors. Adv Nutr. 2014;5(5):457-85.

11. Singh M, Bagewadi A. Comparison of effectiveness of Calendula officinalis extract gel with lycopene gel for treatment of tobacco-induced homogeneous leukoplakia: A randomized clinical trial. Int J Pharm Investig. 2017;7(2):88-93.

12. Nayak A, Anitha B, Bhattacharya A, Podder S. EFFICACY OF LYCOPENE IN COMBINATION WITH VITAMIN E IN MANAGEMENT OF ORAL SUBMUCOUS FIBROSIS-A CLINICAL PROSPECTIVE STUDY. J Adv Med Dent Sci Res. 2015;3(3):21-25.

13. Elizabeth N, Gurumani S, Bala GA, Tukalan G. A comparative study between management of oral submucous fibrosis. J Evolution Med Dent Sci. 2014;3(47):11344-9.

14. Kaur H, Singh A, Goyal S. Use of lycopene in the management of oral submucous fibrosis: a clinical study. International Journal of Medical and Dental Sciences. 2016 July; 5(2): 1229-35.

15. Selvam NP, Dayanand AA. Lycopene in the management of oral submucous fibrosis. Asian J Pharm Clin Res. 2013;6(3):58-61.

16. Singh D, Shashikanth MC, Misra N, Agrawal S. Lycopene and intralesional betamethasone injections in the management of oral submucous fibrosis. J Indian Acad Oral Med Radiol. 2014;26(3):264-8.

17. Katharia SK, Singh SP, Kulshreshtha VK. The effects of placental extract in management of oral-submucous fibrosis. Indian J Pharm. 1992;24(3):181-3.

18. Anshumalee N, Shashikanth MC, Shambulingappa P, Deepak U. Lycopene: A promising antioxidant. J Indian Acad Oral Med Radiol 2007;19(4):458-63.

19. Kitade Y, Watanabe S, Masaki T, Nishioka M, Nishino H. Inhibition of liver fibrosis in LEC rats by a carotenoid, lycopene, or a herbal medicine, Sho-saiko-to. Hepatol Res. 2002;22(3):196-205.

20. Kopuri RK. A Comparative Study of the Clinical Efficacy of Lycopene and Curcumin in the Treatment of Oral Submucous Fibrosis using Ultrasonography. J Int Oral Health. 2016; 8(6):687-91. 